\title{
Effectiveness of Alizapride for Prophylaxis of Nausea and Vomiting after Spinal Anesthesia for Cesarean Section
}

\author{
Ayman Hussein Fahmy Kahla, Nasr Abdel-Aziz Mohammad Saad, Islam Mahmoud \\ Mohamed Mahmoud
}

Department of Anesthesia \& Intensive Care, Faculty of Medicine, Al-Azhar University

Corresponding author: Islam Mahmoud Mohamed Mahmoud, Mobile: 01099066287, Email: shamosa2014@gmail.com

\begin{abstract}
Background: Nausea and vomiting are common side effects in parturients undergoing cesarean delivery performed under spinal anesthesia can be very unpleasant to the patients. The reported incidence of nausea and vomiting during cesarean performed under regional anesthesia varies from $50 \%$ to $80 \%$ when no prophylactic antiemetic is given. Therefore, use of prophylactic antiemetics in parturients undergoing cesarean delivery is recommended by some authors.
\end{abstract}

Objective: In this study, alizapride was evaluated, as a D2 receptor antagonist, on the prevention of nausea and vomiting following Spinal Anesthesia in parturients undergoing elective cesarean section.

Patients and Methods: The study was carried out in AL-Azhar University Hospitals, Obstetric and gynaecology department on 90 patients undergoing an elective, lower segment cesarean section (LSCS). All patients were identified by code number to maintain the privacy of the patients. Any unexpected risks appeared during the course of the research was cleared to the participants and the ethical committee on time. A written informed consent was obtained from all patients. Patients were divided into 3 groups, 30 patients for each group. Group I (Alizapride 50 group): Received intravenous (IV) Alizapride $50 \mathrm{mg}$ diluted in $10 \mathrm{ml}$ of normal saline over 1-5 minutes, immediately after clamping umbilical cord. Group II (Alizapride 100 group): Received intravenous (IV) Alizapride $100 \mathrm{mg}$ diluted in $10 \mathrm{ml}$ of normal saline over 1-5 minutes, immediately after clamping umbilical cord. Group III (Saline group): Received normal saline $10 \mathrm{ml}$, immediately after clamping umbilical cord.

Results: The incidence of nausea and vomiting was significantly decreased in group 2 (Alizapride100 group) compared with group 1 (Alizapride 50 group) and both group was better than group 3 (control group). The use of ondansetron and chlorpheniramine was significantly decreased in group 1 and 2 when compared with group 3.

Conclusion: This study concluded that Alizapride $100 \mathrm{mg}$, given intravenously immediately after clamping umbilical cord would reduce PONV and pruritus in parturients undergoing an elective cesarean section under spinal anesthesia.

Keywords: Postoperative nausea and vomiting, cesarean section, alizapride

\section{INTRODUCTION}

Postoperative nausea and vomiting (PONV) is a common complication for patients undergoing operation. The reported incidence of nausea and vomiting during cesarean performed under regional anesthesia varies from $50 \%$ to $80 \%$ when no prophylactic antiemetic is given. Therefore, the use of prophylactic antiemetics in parturients undergoing cesarean delivery is recommended by some authors ${ }^{(\mathbf{1})}$.

It causes both the physical and psychological distress to the patients as it involves uncontrolled vigorous contraction of muscle, which induces potential adverse effects such as aspiration, dehydration, electrolyte disturbance and surgical site disruption ${ }^{(1)}$. The increase in risk of adverse effects can give rise to additional treatment, monitoring and nursing care, thus, the duration of hospital stay and medical expenses are increased ${ }^{(2)}$.

Pharmacological treatment by administration of antiemetic is the most common strategy to relieve PONV, but it usually leads to the side effects of antiemetic like fatigue, hypotension and dizziness ${ }^{(3)}$. Moreover, pharmacological treatment requires a significant cost and extra management and nursing care, and hence probable lengthening the hospitalization day. Non-pharmacological 
treatment is suggested to be another way out for the patient with PONV ${ }^{(4)}$. A number of treatments have been introduced in order to reduce PONV, such as 5-HT3 antagonists (ondansetron, granisetron and palonosetron), dopamine receptor antagonists, and antihistaminic drugs. However, each of these treatments is associated with critical limiting factors, namely cost with $5-\mathrm{HT}_{3}$ antagonists, extrapyramidal symptoms with dopamine receptor antagonists, excessive sedation and tachycardia with antihistamine drugs ${ }^{(5)}$.

Several classes of drug are used in the management of PONV, but no single class of drug is completely effective in controlling PONV. The D2-receptor antagonist alizapride is a methoxy-2-benzamide derivative, new drug structurally related to metoclopramide for treatment of nausea and vomiting. ${ }^{(7)}$

Alizapride is an established antiemetic that is widely used in oncology and perioperative medicine. Alizapride has a favorable safety profile with only infrequently occurring side effects, which include headache, dizziness, dry mouth and extrapyramidal syndromes. Alizapride $50 \mathrm{mg}$ I.V. dose reduced the intensity of spinal morphine-induced pruritus ${ }^{(8,10)}$. As it is very well tolerated in much higher doses, thus, it would be important to assess its antipruritic activity using a higher dose (100 mg I.V.) ${ }^{(9}$, 11).

\section{AIM OF THE WORK}

This study aimed to evaluate the efficacy and safety of Alizapride in preventing emetic symptoms during cesarean delivery under spinal anesthesia.

\section{Patients and Methods}

Design: This prospective study has been designed to testify that spinal- induced nausea and vomiting could be minimized with the use of intravenous alizapride associated to preanesthesia administration of crystalloid (10$20 \mathrm{ml} / \mathrm{kg}$ ), in parturients undergoing cesarean section. Patients were randomly enrolled to one of the three groups (Alizapride 50 group, Alizapride100 group versus placebo control group). After clamping umbilical cord, patients in Alizapride 50 group received Alizapride $50 \mathrm{mg}$ diluted to $10 \mathrm{ml}$ of normal saline over 1-5 minutes. Patients in Alizapride 100 group received Alizapride100 mg diluted to $10 \mathrm{ml}$ of normal saline over 1-5 minutes. Patients in placebo group received $10 \mathrm{ml}$ of normal saline (control group) at the same time and rate.

Setting: The study was carried out in ALAzhar University Hospitals.

Inclusion criteria: After obtaining the Research/Ethics committee approval and written informed consents, nighnty adult obstetric patients who were ASA physical status I, II, between 18 and 40 years of age, with weight $60 \mathrm{~kg}$ to $80 \mathrm{~kg}$ and undergoing an elective cesarean section with spinal anesthesia constituted the population of this study. The decision to proceed with operative delivery was made by obstetric team independent of the investigators.

Exclusion criteria: Parturient who had smoker habit, Obstetric complications, Allergy to Alizapride, Evidence of fetal compromise, Patients who had motion sickness, gastrointestinal disease, Administration of antiemetic medication in the previous 24 hours, Any contraindication for spinal anesthesia will be excluded.

Preoperative evaluation: The patient was screened for suitability by: 1- History including assessment of the cardio-respiratory status. 2- Physical examination: chest and heart auscultation and airway assessment. 3Investigations: complete blood picture, coagulation profile, liver function, kidney function, ECG.

Patient monitoring (standard monitoring): Pulse oximetry, ECG and Noninvasive blood pressure monitoring $5 \mathrm{~min}$ interval inside the operating room.

Anesthetic technique: In the preanesthesia room, a peripheral 18-gauge cannula was inserted. All patients received pre hydration with $15 \mathrm{ml} / \mathrm{kg}$ of Ringers lactate over a period of 20 minutes before spinal anesthesia and no additional fluid was given other than that required to keep IV peripheral cannula patent.

The spinal technique was performed with the patient in sitting position at L3-L4, L2-L3 interspace using a 25-gauge spinal needle under all aseptic precautions. When free flow of cerebrospinal fluid was obtained $12.5 \mathrm{mg}$ of $0.5 \%$ bupivacaine and $25 \mu \mathrm{g}$ fentanyl was injected slowly without barbotage. After withdrawal of spinal needle an antiseptic seal was applied at the site of lumbar puncture and the patients were then positioned 
supine, with 15 degree left lateral tilt. Subsequently, the patients were placed in the position and bladder catheter was inserted.

Usually, data regarding age, height and weight, hemodynamic parameters, the presences of nausea, vomiting, discomfort or inadequate analgesia was collected in the anesthesiology records.

Motor block was assessed after the spinal anesthesia using the modified Bromage scale, and scored as:

$0=$ no motor block,

$1=$ being unable to move the hip,

2 = being unable to move the knee,

and

$3=$ being unable to move the ankle.

The height of the sensory block was assessed using pin prick sensory method. Surgery was allowed to proceed after a block to T6 had been established and the block level at the end of surgery was documented. These studied drugs were administered I.V. immediately after clamping of the umbilical cord. Nausea and vomiting were recorded in the three groups every 4 hour in first $24 \mathrm{~h}$. Side effects of spinal anesthesia was recorded.

Hypotension was defined as a decrease in the systolic arterial pressure (SAP) more than $20 \%$ from the baseline reading or a decrease of SAP to less than $90-100 \mathrm{mmHg}$ or MBP $<70 \mathrm{mmHg}$ as absolute value and was treated by boluses of ephedrine in doses of 5 $\mathrm{mg}$.

Heart rate $<60$ beats/min was treated with Atropine $0.5 \mathrm{mg}$.

At delivery all patients received 20 IU of oxytocin IV and no further oxytocin was given intra-operatively.

Nausea is defined as a subjectively unpleasant sensation associated with awareness of the urge to vomit, and vomiting is the forceful expulsion of gastric contents from the mouth. Retching- defined as the labored, spasmodic, rhythmic contractions of the respiratory muscles without the expulsion of gastric contents- was not assessed as a separate entity and patients who experienced it were classified as nauseous.

The details of any other adverse effects are noted throughout the study following either general questioning of the patients by these anesthesiologists or spontaneously mentioned by the patients. The intraoperative IV sedative medications, fluid administered, and estimated blood loss were also recorded. In the event of excessive blood loss (>900 $\mathrm{ml})$, the patient was excluded from the study and treated appropriately.

The following indices were taken and statistically analyzed: Nausea and vomiting baseline, at 4, 6, 12, $24 \mathrm{~h}$ after injection of studied drug. Pruritus - baseline, at 4, 6, 12, $24 \mathrm{~h}$ after injection of studied drug. Painbefore beginning surgery, 2, 6, 12, 24 hours after injection of studied drugs. The adverse effects of studied drug including, headache, dizziness, hypotension, sedation, extrapyramidal manifestation and hiccup were recorded.

\section{Statistical analysis:}

Recorded data were analyzed using the statistical package for social sciences, version 20.0 (SPSS Inc., Chicago, Illinois, USA). Quantitative data were expressed as mean \pm standard deviation (SD). Qualitative data were expressed as frequency and percentage.

\section{The following tests were done:}

- A one-way analysis of variance (ANOVA) when comparing between more than two means.

- Post Hoc test: Least Significant Difference (LSD) was used for multiple comparisons between different variables.

- Chi-square $\left(\mathrm{x}^{2}\right)$ test of significance was used in order to compare proportions between two qualitative parameters.

- The confidence interval was set to $95 \%$ and the margin of error accepted was set to $5 \%$. So, the p-value was considered significant as the following:

- Probability (P-value)

- P-value $\leq 0.05$ was considered significant.

- P-value $\leq 0.001$ was considered as highly significant.

- P-value >0.05 was considered insignificant.

\section{RESULTS}

Significant decreases in PONV were observed among groups ( $P$ value $<0.05)$. Differences were observed among groups from $2 \mathrm{~h}$ to $24 \mathrm{~h}$. Those in Group B had a highly significance lower incidence $(P$ value < 0.001 ), followed by group A and at least group $\mathrm{C}$ which had least effect (Table 1). 
Effectiveness of Alizapride for Prophylaxis of Nausea and Vomiting after...

Table (1): Comparison between groups regarding to nausea and vomiting VAS

\begin{tabular}{|c|c|c|c|c|c|}
\hline $\begin{array}{c}\text { Nausea and Vomiting } \\
\text { VAS }\end{array}$ & $\begin{array}{c}\text { Group A } \\
\text { Alizapride } \\
\text { 50mg }(n=30)\end{array}$ & $\begin{array}{c}\text { Group } \\
\text { BAlizapride } \\
\text { 100mg } \\
(n=30)\end{array}$ & $\begin{array}{c}\text { Group C } \\
\text { Normal saline } \\
(n=30)\end{array}$ & $\mathbf{x} 2$ & p-value \\
\hline \multicolumn{6}{|l|}{ Baseline } \\
\hline No & $19(63.3 \%)$ & $17(56.7 \%)$ & $17(56.7 \%)$ & \multirow{4}{*}{1.888} & \multirow{4}{*}{0.756} \\
\hline Mild 1-3 & $5(16.7 \%)$ & $8(26.7 \%)$ & $5(16.7 \%)$ & & \\
\hline Moderate 4-7 & $6(20.0 \%)$ & $5(16.7 \%)$ & $8(26.7 \%)$ & & \\
\hline Severe 8-10 & $0(0.0 \%)$ & $0(0.0 \%)$ & $0(0.0 \%)$ & & \\
\hline \multicolumn{6}{|l|}{2 hrs } \\
\hline $\mathrm{No}$ & $25(83.3 \%)$ & $27(90.0 \%)$ & $19(63.3 \%)$ & \multirow{4}{*}{7.926} & \multirow{4}{*}{0.094} \\
\hline Mild 1-3 & $3(10.0 \%)$ & $3(10.0 \%)$ & $7(23.3 \%)$ & & \\
\hline Moderate 4-7 & $2(6.7 \%)$ & $0(0.0 \%)$ & $4(13.3 \%)$ & & \\
\hline Severe $8-10$ & $0(0.0 \%)$ & $0(0.0 \%)$ & $0(0.0 \%)$ & & \\
\hline \multicolumn{6}{|l|}{$6 \mathrm{hrs}$} \\
\hline No & $28(93.3 \%)$ & $29(96.7 \%)$ & $20(66.7 \%) a b$ & \multirow{4}{*}{13.127} & \multirow{4}{*}{$<0.001 * *$} \\
\hline Mild 1-3 & $2(6.7 \%)$ & $1(3.3 \%)$ & $10(33.3 \%)$ & & \\
\hline Moderate 4-7 & $0(0.0 \%)$ & $0(0.0 \%)$ & $0(0.0 \%)$ & & \\
\hline Severe 8-10 & $0(0.0 \%)$ & $0(0.0 \%)$ & $0(0.0 \%)$ & & \\
\hline \multicolumn{6}{|l|}{12 hrs } \\
\hline $\mathrm{No}$ & $29(96.7 \%)$ & $30(100.0 \%)$ & $20(66.7 \%) \mathrm{ab}$ & \multirow{4}{*}{18.849} & \multirow{4}{*}{$<0.001 * *$} \\
\hline Mild 1-3 & $1(3.3 \%)$ & $0(0.0 \%)$ & $10(33.3 \%)$ & & \\
\hline Moderate 4-7 & $0(0.0 \%)$ & $0(0.0 \%)$ & $0(0.0 \%)$ & & \\
\hline Severe $8-10$ & $0(0.0 \%)$ & $0(0.0 \%)$ & $0(0.0 \%)$ & & \\
\hline \multicolumn{6}{|l|}{24 hrs } \\
\hline No & $29(96.7 \%)$ & $30(100.0 \%)$ & $21(70.0 \%) \mathrm{ab}$ & \multirow{4}{*}{16.425} & \multirow{4}{*}{$<0.001 * *$} \\
\hline Mild 1-3 & $1(3.3 \%)$ & $0(0.0 \%)$ & $9(30.0 \%)$ & & \\
\hline Moderate 4-7 & $0(0.0 \%)$ & $0(0.0 \%)$ & $0(0.0 \%)$ & & \\
\hline Severe 8-10 & $0(0.0 \%)$ & $0(0.0 \%)$ & $0(0.0 \%)$ & & \\
\hline
\end{tabular}

This table show statistically significant difference between groups regarding to nausea and vomiting VAS from $6 \mathrm{hrs}$ to $24 \mathrm{hrs}$.

Significant decreases in the incidence and severity of pruritus were observed among groups ( $P$ value $<0.05$ ). Differences were observed between groups from $2 \mathrm{~h}$ to $24 \mathrm{~h}$. Those in Group B and A had a significantly lower incidence as $P$ value $<0.05$ (Table 2 ). $2 \mathrm{hrs}$ to $24 \mathrm{hrs}$.

This table show statistically significant difference between groups according to pruritus from

Significant Decreases in use of Onansetron and Chlorpheniramine were observed in all groups $(P$ Value $<0.05)$. Differences were observed between groups from $2 \mathrm{~h}$ to $24 \mathrm{~h}$. Those in group A and B had significantly lower incidence of use of such drug As $P$ Value $<0.05$ (Table 3). 
Table (2): Comparison between groups regarding to pruritus by 4 point scale.

\begin{tabular}{|c|c|c|c|c|c|}
\hline Pruritus by 4 Point Scale & $\begin{array}{c}\text { GroupA } \\
\text { Alizapride 50mg } \\
(n=30)\end{array}$ & $\begin{array}{c}\text { Group B } \\
\text { Alizapride } \\
\text { 100mg }(n=30)\end{array}$ & $\begin{array}{c}\text { Group C } \\
\text { Normal saline } \\
(n=30)\end{array}$ & $\mathbf{x} 2$ & p-value \\
\hline \multicolumn{6}{|l|}{ Baseline } \\
\hline No & $21(70.0 \%)$ & $19(63.3 \%)$ & $21(70.0 \%)$ & \multirow{4}{*}{2.224} & \multirow{4}{*}{0.695} \\
\hline Mild & $7(23.3 \%)$ & $7(23.3 \%)$ & $8(26.7 \%)$ & & \\
\hline Moderate & $2(6.7 \%)$ & $4(13.3 \%)$ & $1(3.3 \%)$ & & \\
\hline Severe & $0(0.0 \%)$ & $0(0.0 \%)$ & $0(0.0 \%)$ & & \\
\hline \multicolumn{6}{|l|}{$2 \mathrm{hrs}$} \\
\hline No & $29(96.7 \%)$ & $29(96.7 \%)$ & $21(70.0 \%) \mathrm{ab}$ & \multirow{4}{*}{13.870} & \multirow{4}{*}{$0.008 *$} \\
\hline Mild & $1(3.3 \%)$ & $1(3.3 \%)$ & $6(20.0 \%)$ & & \\
\hline Moderate & $0(0.0 \%)$ & $0(0.0 \%)$ & $3(10.0 \%)$ & & \\
\hline Severe & $0(0.0 \%)$ & $0(0.0 \%)$ & $0(0.0 \%)$ & & \\
\hline \multicolumn{6}{|l|}{6 hrs } \\
\hline No & $29(96.7 \%)$ & $30(100.0 \%)$ & $21(70.0 \%) \mathrm{ab}$ & \multirow{4}{*}{16.575} & \multirow{4}{*}{$0.002 *$} \\
\hline Mild & $1(3.3 \%)$ & $0(0.0 \%)$ & $7(23.3 \%)$ & & \\
\hline Moderate & $0(0.0 \%)$ & $0(0.0 \%)$ & $2(6.7 \%)$ & & \\
\hline Severe & $0(0.0 \%)$ & $0(0.0 \%)$ & $0(0.0 \%)$ & & \\
\hline \multicolumn{6}{|l|}{12 hrs } \\
\hline No & $30(100.0 \%)$ & $30(100.0 \%)$ & $22(73.3 \%) \mathrm{ab}$ & \multirow{4}{*}{17.561} & \multirow{4}{*}{$0.002 *$} \\
\hline Mild & $0(0.0 \%)$ & $0(0.0 \%)$ & $6(20.0 \%)$ & & \\
\hline Moderate & $0(0.0 \%)$ & $0(0.0 \%)$ & $2(6.7 \%)$ & & \\
\hline Severe & $0(0.0 \%)$ & $0(0.0 \%)$ & $0(0.0 \%)$ & & \\
\hline \multicolumn{6}{|l|}{$24 \mathrm{hrs}$} \\
\hline No & $30(100.0 \%)$ & $30(100.0 \%)$ & $22(73.3 \%) \mathrm{ab}$ & \multirow{4}{*}{17.561} & \multirow{4}{*}{$0.002 *$} \\
\hline Mild & $0(0.0 \%)$ & $0(0.0 \%)$ & $6(20.0 \%)$ & & \\
\hline Moderate & $0(0.0 \%)$ & $0(0.0 \%)$ & $2(6.7 \%)$ & & \\
\hline Severe & $0(0.0 \%)$ & $0(0.0 \%)$ & $0(0.0 \%)$ & & \\
\hline
\end{tabular}

$x^{2}:$ Chi-square test; $p$-value $>0.05 \mathrm{NS} ; *$-value $<0.05 \mathrm{~S}$;

a: Significant difference group $A$

b: Significant difference group B

Table (3): Comparison between groups regarding to need of Ondanseyron, Chlorpheniramine, Ephedrine $5 \mathrm{mg}$ and pethedine.

\begin{tabular}{|l|c|c|c|c|c|}
\hline & $\begin{array}{c}\text { Group A } \\
\text { Alizapride } \\
\mathbf{5 0 m g} \\
(\boldsymbol{n}=30)\end{array}$ & $\begin{array}{c}\text { Group B } \\
\text { Alizapride } \\
\mathbf{1 0 0 m g} \\
(\boldsymbol{n}=30)\end{array}$ & $\begin{array}{c}\text { Group C } \\
\text { Normal saline } \\
(\boldsymbol{n}=30)\end{array}$ & $\mathbf{x} 2$ & p-value \\
\hline Ondansetron 4 mg intake & $4(13.3 \%)$ & $1(3.3 \%)$ & $8(26.7 \%) b$ & 6.653 & $0.036^{*}$ \\
\hline Chlorpheniramine intake & $0(0.0 \%)$ & $0(0.0 \%)$ & $10(33.3 \%) \mathrm{ab}$ & 22.500 & $<0.001^{* *}$ \\
\hline Pethedine 50 mg intake & $3(10.0 \%)$ & $2(6.7 \%)$ & $5(16.7 \%)$ & 1.575 & 0.455 \\
\hline Ephedrine 5 mg intake & $4(13.3 \%)$ & $6(20.0 \%)$ & $3(10.0 \%)$ & 1.259 & 0.533 \\
\hline
\end{tabular}

$x^{2}$ : Chi-square test;

p-value $>0.05 \mathrm{NS} ; *$ p-value $<0.05 \mathrm{~S} ; * *$-value $<0.001 \mathrm{HS}$

a: Significant difference group $A$

b: Significant difference group $B$ 
This table show statistically significant difference between groups regarding to ondansetron and chlorpheniramine.

\section{DISCUSSION}

Spinal anesthesia is frequently used for cesarean section because it is a simple technique, which produces fast and highly effective anesthesia whilst avoiding the morbidity and mortality associated with general anesthesia. Moreover the quality of analgesia is better and blood loss is minimized $(12,13)$

Postoperative nausea and vomiting (PONV) is a common complication for patients undergoing operation. It causes both the physical and psychological distress to the patients as it involves uncontrolled vigorous contraction of muscle, which induces potential adverse effects such as aspiration, dehydration, electrolyte disturbance and surgical site disruption ${ }^{(14)}$.

In previous studies, the incidence of PONV in patients who did not receive antiemetic prophylaxis was as high as $70-80 \%$ $(15,16)$. Among the many factors, female gender, past history of PONV and motion sickness, use of opioids, nitrous oxide and non-smoking history are the in dependent predictors for PONV ${ }^{(17)}$.

A number of treatments have been introduced in order to reduce PONV, such as 5-HT3 antagonists (ondansetron, granisetron and palonosetron), dopamine receptor antagonists, and antihistamine drugs. However, each of these treatments is associated with critical limiting factors, namely cost with $5-\mathrm{HT}_{3}$ antagonists, extrapyramidal symptoms with dopamine receptor antagonists, excessive sedation and tachycardia with antihistamine drugs ${ }^{(18)}$.

Alizapride used in particular, because it has the same effect of metoclopramide with less side effect and for it anti-pruritic action. The selection of doses was based on previous studies reporting they were safe and effective $(20,21)$.

In this study, patients received the same type of anesthesia and underwent the same type of surgery.

Moreover, the variables age, gender, weight, height, physical status, non-smoker status, history of PONV, preoperative fasting time, duration of anesthesia, amount of fluid infused during surgery and time of PACU stay (possible confounding biases) had homogeneous distribution between groups. This is important because the differences between groups could be attributed to the different antiemetic combinations administered.

In this randomized double-blind study, after obtaining approval from Al Azhar University Hospital ethics committee and written informed consent from each partureints undergoing elective cesarean delivery. Nighnty partureints were enrolled randomly. Group (A), 30 female patients received Alizapride $50 \mathrm{mg}$ immediately after clamping umbilical cord. Group (B), 30 female patients received Alizapride $100 \mathrm{mg}$ immediately after clamping umbilical cord. Group (C), 30 female patients received $10 \mathrm{ml}$ normal saline immediately after clamping umbilical cord. Alizapride $100 \mathrm{mg}$ was shown to be more effective than other group.

In our study, the results showed no statistically significant difference in the demographic data in the studied groups as regards age, sex, height, weight and duration of surgery (as $\mathrm{p}$ value $>0.05$ ).

This study revealed that incidence and severity of PONV and Pruritus were reduced with the use of IV Alizapride $100 \mathrm{mg}$ given after clamping umbilical cord in parturient undergoing elective cesarean section. The use of ondansetron $4 \mathrm{mg}$ and chlorpheniramate was also significantly reduced with Alizapride.

There was statistically significant difference between the three groups regarding the incidence and severity of postoperative nausea and vomiting (PONV) during the first 24 hours postoperatively. Group Alizapride 100 was better than group Alizapride 50 (pvalue < 0.001) and both group was better than saline group. Group B (alizapride 100), show highly improvement from $56.7 \%$ at base to $90.0 \%$ after 2 h, $96.7 \%$ after 6 h, $100.0 \%$ after $12 \mathrm{~h}$ and the reset of $24 \mathrm{~h}$. Group A (alizapride 50), show improvement from $63.3 \%$ at base to $83.3 \%$ after $2 \mathrm{~h}, 93.3 \%$ after $6 \mathrm{~h}, 96.7 \%$ after $12 \mathrm{~h}$ and the reset of $24 \mathrm{~h}$.

Group C (Saline group), show slight improvement from $56.7 \%$ at base to $63.3 \%$ after $2 \mathrm{~h}, 66.7 \%$ after $6 \mathrm{~h}, 70.0 \%$ after $12 \mathrm{~h}$ and the reset of $24 \mathrm{~h}$.

Regarding severity of PONV in the first 24 hours postoperatively there was statistically difference between the two groups. Group alizapride 100 was better than 
alizapride 50 (p-value < 0.001) and both group was better than saline group.

The Ondansetron dose needed during the first 24 hours postoperatively was significantly lower in alizapride 100 group in relation to other group Alizapride 50, and saline ( $\mathrm{p}$-value $<0.05$ ).

Regarding the effect on pruritus group alizapride 100 and 50 show better effect on lowering the incidence and severity of pruritus than saline group ( $p$ value $<0.002$ ).

Regarding incidence of complications there were no statistically difference among the three groups with mild difference between groups showing that Alizapride 50 group was lower in incidence of complications $(13.3 \%)$ in relation to Alizapride 100 (16.7\%) and less in saline group $(10 \%)$.

Regarding sedation and extrapyramidal manifestation there were no significant difference between three group.

In agreement with the results of this study regarding prevention of post-operative nausea and vomiting, Stienstra et al. ${ }^{(22)}$ Evaluated the efficacy of Alizapride $100 \mathrm{mg}$ in prevention of post-operative nausea and vomiting. The authors hypothesized that the use of IV alizapride $100 \mathrm{mg}$, droperidol $1 \mathrm{mg}$ and ondansetron $8 \mathrm{mg}$ intravenously was equally effective in the treatment of PONV after gynaecological procedures and that the newer drugs alizapride and ondansetron offer no advantage over droperidol.

HUYS et al. concluded that the use of high dose of alizapride was significantly better in preventing severe nausea and episodes of vomiting and of minor side effect as sedation and extrapyramidal manifestation compared with high dose of dompridone ${ }^{(23)}$.

HORTA and VIANNA stated that alizapride had significantly lower incidences of pruritus. As for the prevention of moderate and severe pruritus, alizapride had better effect compared with propofol and droperidol ${ }^{(24)}$.

In contrary to the present study results, JOSS and GALEAZZI concluded that alizapride did not prove much better effect in prevention of nausea and vomiting compared with high dose of metoclopramide and patients preferred the latter regimen ${ }^{(25)}$.

\section{CONCLUSION}

This study concluded that Alizapride $100 \mathrm{mg}$, given intravenously immediately after clamping umbilical cord reduce PONV and pruritus in parturients undergoing an elective cesarean section.

\section{REFERENCES}

1. Dewinter G, Teunkens A, Vermeulen K, Devroe S, Van Hemelrijck J, Meuleman C, Vergote I, Fieuws S, Van de Velde M, Rex S (2016) : Alizapride and ondansetron for the prevention of postoperative nausea and vomiting in patients undergoing laparoscopic gynaecological surgery: A double-blind, randomised, placebocontrolled noninferiority study. Eur J Anaesthesiol., 33 (2): 96-103.

2. Horta ML, Morejon LC, da Cruz AW, Dos Santos GR, Welling LC, Terhorst L, Costa RC, Alam RU (2006): Study of the prophylactic effect of droperidol, alizapride, propofol and promethazine on spinal morphine-induced pruritus. $\mathrm{Br} \mathrm{J}$ Anaesth., 96 (6): 796-800.

3. Horta ML, Vianna PT (2003) : Effect of intravenous alizapride on spinal morphine-induced pruritus. Br J Anaesth., 91 (2): 287-9.

4. Booij LH, Rachmat S, Bulder ER (1988): Alizapride in prevention of postoperative nausea and vomiting. Neth $\mathrm{J}$ Surg., 40 (1): 6-9.

5. Stienstra R, Samhan YM, el-Mofty $M$, de Bont LE, Bovill JG (1997): Doubleblind comparison of alizapride, droperidol and ondansetron in the treatment of postoperative nausea. Eur J Anaesthesiol, 14(3): 290- 4.

6. Chatterjee S1, Rudra A, Sengupta $S$ (2016): Concepts in the Management of Postoperative Nausea and Vomiting.:Anesthesiology Research and Practice 2016: 4281719

7. Carlisle J, Stevenson CA (2014) Drugs for preventing postoperative nausea and vomiting. Cochrane Database Syst Rev., https://patientsafe.files.wordpress.com/201 6/03/neostigmine-ponv-yes.pdf

8. Myklejord DJ1, Yao L, Liang $\mathrm{H}$, Glurich I (2012): Consensus guideline adoption for managing postoperative nausea and vomiting. WMJ., 111 (5): 20713.

9. Jelting Y1, Klein C1, Harlander T1, Eberhart L2, Roewer N1, Kranke P1 (2017): Preventing nausea and vomiting in women undergoing regional anesthesia for 
cesarean section: challenges and solutions. Local Reg Anesth., 10: 83-90.

10. Rosow CE, Moss J, Philbin DM, Savarese JJ (1982): Histamine release during morphine and fentanyl anesthesia. Anesthesiology, 56: 93-6

11. Hermens JM, Ebertz JM, Hanifin JM, Hirshman CA (1985) :Comparison of histamine release in human skin mast cells induced by morphine, fentanyl, and oxymorphone. Anesthesiology, 62(2), 124-129.

12. Bucklin BA, Hawkins JL, Anderson JR, Ullrich FA (2005): Obstetric anesthesia workforce survey: twenty-year update. Anesthesiology, 103: 645.

13. Hussain N, Tayab $S$, Mahmood $T$ (2002) Spinal anaesthesia for caesarean section. J Surg Pakistan, 7: 19-21.

14. Dewinter G, Teunkens A, Vermeulen K, Devroe S, Van Hemelrijck J, Meuleman C, Vergote I, Fieuws S, Van de Velde M, Rex S (2016): Alizapride and ondansetron for the prevention of postoperative nausea and vomiting in patients undergoing laparoscopic gynaecological surgery: Adouble-blind, randomised, placebo-controlled noninferiority study. Eur JAnaesthesiol., 33 (2): 96-103.

15. Moussa AA, Oregan PJ (2007): Prevetion of postoperative nausea and vomiting in patients undergoing laparoscopic bariatric surgery Granisetron alone vs granisetron combined with dexamethasone/droperidol. M.E.J. Anesth., 19 (2): 367- 368.

16. Mendes MN, Monteiro RS, Cruz M (2009) : Profi laxia de náuseas e vômitos pós-operatórios em obesos mórbidos submetidos a gastroplastias por laparoscopias. Estudo comparativo entre três métodos. Rev Bras Anestesiol., 59 (5): 570-576.

17. Chandrakantan A, Glass PS (2011): Multimodal therapies for postoperative nausea and vomiting, and pain. $\mathrm{Br} \mathrm{J}$ Anesth., 33(4):629-50

18. Stienstra R, Samhan YM, el-Mofty M, de Bont LE, Bovill JG (2011): Doubleblind comparison of alizapride, droperidol and ondansetron in the treatment of postoperative nausea. Eur J Anaesthesiol., 14 (3): 290-4.

19. Myklejord DJ1, Yao L, Liang $H$, Glurich I (2012): Consensus guideline adoption for managing postoperative nausea and vomiting. WMJ., 111 (5): 20713; quiz 214.

20. Rosow CE, Moss J, Philbin DM, Savarese JJ (1982): Histamine release during morphine and fentanyl anesthesia. Anesthesiology, 56: 93-6

21. Saller R, Hellenbrecht D (1985) : Comparison of the antiemetic efficacy of two high dose benzamides, metoclopramide and Alizapride against cis-platinum induced emesis.Cancer Treat Rep., 69: 1301-1303.

22. Stienstra R, Samhan YM, El-Mofty M, De Bont LEA, Bovill JG (2003) :Double-blind comparison of alizapride, droperidol and ondansetron in the treatment of post-operative nausea ,European journal of anaesethsiology, 14(3):2904

23. Huys J, Troch M, Bourguignon RP, Smets P (2008): Alizapride versus highdose domperidone: a double-blind comparative study in the management of cis-platinum-induced emesis, Current Medical Research and Opinion, 9(6):4006.

24. Horta ML, Vianna PTG (2003) : Effect of intravenous alizapride on spinal morphine-induced pruritus. Br J Anaesth., 91(2): 287-9

25. Joss RA, Galeazzi RL (1986): THE ANTI-EMETIC ACTIVITY OF HIGH DOSE ALIZAPRIDE AND HD MCP IN PATIENTS RECEIVING CANCER CHEMOTHERAPY: A PROSPECTIVE DOUBLE-BLIND TRIAL. CLIN PHARMAC THER. , 39: 619-624. 